\title{
多孔質アルミニウムアノード酸化皮膜と熱水との反応 $\mathrm{V}$.水和挙動に対する熱水中の添加剤の効果
}

\author{
甲田 満*，高橋 英明**，永山 政一**
}

\section{Reaction of Porous Anodic Oxide Films on Aluminum with Hot Water V. Effects of Additives in Hot Water on the Hydration Behavior}

\author{
Mitsuru KODA*, Hideaki TAKAHASHI** and Masaichi NAGAYAMA**
}

\begin{abstract}
Porous anodic oxide films formed on $\mathrm{Al}$ in an oxalic acid solution were hydrated in water at 99.5 ${ }^{\circ} \mathrm{C}$ with and without additions of chromate, phosphate or nickel acetate. The hydrated films were then dissolved in a chromic acid-phosphoric acid solution. The changes in film structure during the hydration and dissolution experiments were followed by gravimetry and by impedance measurements in a neutral borate solution.

(1) As in pure hot water, pores of the film were filled up (or sealed) with hydrous oxide in a short time in waters containing chromate and nickel acetate, although slight dissolution of the film was observed. The water with phosphate did not hydrate the film but dissolved it to some extent.

(2) In the chromic acid-phosphoric acid solution, films hydrated in chromate-containing hot water dissolved faster and films hydrated in hot water containing nickel acetate dissolved slower than those hydrated in pure hot water. For all films, the dissolution rate was controlled by the dissolution of hydrous oxide which fills up the pores. The dissolution rate in general decreased with increasing electric resistance of the hydrous oxide.

The significance of the three existing methods of verifying the degree of "sealing", the coloring method, the impedance measuring method and the acid dissolution method, is discussed.
\end{abstract}

\section{1. 緒 \\ 言}

多孔質 $\mathrm{Al}$ アノード酸化皮膜に熱水処理を施すと，そ の耐食性が著しく増加する。著者らは前報までの研究 ${ }^{1)}$ 〜4に扣いて, シュウ酸化成皮膜を沸卜ウ純水中に浸セ キし, その重量, 電気的性質および酸溶解挙動の時間的 変化を追跡し，皮膜の耐食性の向上が，基本的には，“熱 水との接触により生成した水和酸化物が皮膜の細孔を 埋めつくす（封孔）ため”であると結論した。

工業的に用いる処理液は単なる純水ではなく，これに クロム酸塩, ニッケル塩などの添加剂を加える場合が多 $(5) \sim 7)$ 。

クロム酸塩は, 処理のさいに孔中に封入され，素地金

* 北海道大学工学部（干060 札幌市北区北13条西8丁目） Fac. of Engr., Hokkaido Univ.

（現）日新製鋼秼阪神研究所（干592 堺市石津西町五番地） Hanshin R\&D Laboratories, Nisshin Steel Co., LTD. (5, Ishizu Nishi-machi, Sakai-shi, Osaka 592)

** 北海道大学工学部 (干060 札幌市北区北13条西8丁目) Fac. of Engr., Hokkaido Univ. (N 13, W 8, Kita-ku, Sapporo-shi 060)
属の腐食抑制剤として働くと考えられている。また， ッケル塩は, 処理のさい加水分解を起こして水和ニッケ ル酸化物の沈影となり，細孔の孔埋めを促進するととも に, あらかじめ染色処理した皮膜については, 染料と難 溶性の塩を形成し，その流出を防止すると言われている。 一般に，熱水にリン酸塩が混入すると処理効果が著 しく減少すると言われているが5),8),9), Murphy ${ }^{10), 11) ~ ら ~}$ はリン酸塩の添加により皮膜の耐食性がむしろ向上する と主張している。

本研究に拀いては，シュウ酸溶液中でアノード酸化に よりアルミニウムの多孔質酸化皮膜を化成し，これをク ロム酸塩, ニッケル塩またはリン酸塩を含む水溶液中に 浸セキ処理し，引き続き処理皮膜を酸溶液中で化学溶解 処理した。そしてこれらの両過程における皮膜の重量および 電気的性質の時間による変化を追跡し，その挙動を純熱 水のみで処理した皮膜についてのそれと比較した。その 結果に基ついて, 各種添加イオンの効果扰よび封孔度試 験の意義を論じた。 


\section{2. 実 験 方 法}

\section{2-1 アノード酸化}

試料には電解研摩した $99.994 \%$ 高純度 Al 䇴（1× $3 \mathrm{~cm}$ ，枝付き）を用い，電解液 $2 \% \mathrm{H}_{2} \mathrm{C}_{2} \mathrm{O}_{4} \cdot 2 \mathrm{H}_{2} \mathrm{O}$ 溶液 $\left(30^{\circ} \mathrm{C}, 200 \mathrm{ml}\right)$ 中, 空気開放カク抖条件下で, $\mathrm{i}_{\mathrm{a}}=$ $10 \mathrm{~mA} / \mathrm{cm}^{2}$ (端子電圧は $\mathrm{V}_{\mathrm{a}}=41$ volt ) の一定電流を与えて, $\mathrm{t}_{\mathrm{a}}=10 \mathrm{~min}$ アノード酸化した。生成する皮膜の厚さはH $=2.7 \mu \mathrm{m}$, 多孔度は $\alpha=0.1$, 重量は $\mathrm{W}_{\mathrm{ox}}=2.14 \mathrm{mg} / \mathrm{cm}^{2}$ であっ $た^{1), 2)}$ 。

\section{2-2 熱水処理}

処理溶液 ( $50 \mathrm{~m} l$, カク拌) として以下のものを用いた。 (1) $0.05 \mathrm{M} \mathrm{CrO}_{4}{ }^{2-}$ 溶液 ( $\mathrm{K}$ 塩, $\mathrm{pH}=6.9$ ), (口) $0.5 \mathrm{M} \mathrm{CrO}_{4}{ }^{2-}$ 溶液 ( $\mathrm{K}$ 塩, $\mathrm{pH}=6.8$ ), ( $) 5 \mathrm{~g} / \mathrm{l}$ Sealing salt AS 溶液 (酢 酸二ッケル十界面活性剂, Sandz 社製, 以下 $\mathrm{AS}$ 溶液と 略す), (二 $10^{-3} \mathrm{M} \mathrm{PO}_{4}{ }^{3-}$ 溶液 ( $\mathrm{Na}$ 塩, $\mathrm{pH}=7.0$ ) および(ホ) 蒸留水。処理液 $50 \mathrm{~m} l$ に 1 個の試料を浸して実験を行い, 処理液は実験の都度新しいものにとりかえた。処理温度 は $99.5^{\circ} \mathrm{C}$, 時間は $t_{h}=0 \sim 60 \mathrm{~min}$ とした $\left(t_{h}=0 \mathrm{~min}\right.$ は無 処理に相当)。

\section{2-3 化学溶解}

熱水処理後, 試料をりン酸一クロム酸混合溶液（リン 酸 $35 \mathrm{~m} l+$ 無水ク口ム酸 $20 \mathrm{~g}$ を蒸留水に溶かし $1 l$ とし たもの， $50^{\circ} \mathrm{C}$ ) 中に浸セキし，時間 $t_{d}$ を種々変化して 酸溶解した。

\section{2-4 重量測定}

試料の重量を(H)アノード酸化後 $\left(\mathrm{W}_{\mathrm{a}}\right)$, (口)熱水処理後 $\left(\mathrm{W}_{\mathrm{h}}\right)$ および け熔解の種々の時点 $\mathrm{t}_{\mathrm{d}}$ において $\left(\mathrm{W}_{\mathrm{d}}\right)$ 測 定し, （ｉ）熱水処理による試料の重量増加 $\Delta \mathrm{W}_{\mathrm{h}}=\mathrm{W}_{\mathrm{h}}$ $\mathrm{W}_{\mathrm{a}}$ および, (ii)化学溶解による試料の重量减少 $\Delta \mathrm{W}_{\mathrm{d}}$ $=\mathrm{W}_{\mathrm{h}}-\mathrm{W}_{\mathrm{d}}$ を算出した ${ }^{1)}$ 。

\section{2-5 インピーダンス測定}

熱水処理したのち, 試料を 0.5 $\mathrm{M} \mathrm{H}_{3} \mathrm{BO}_{3}-0.05 \mathrm{M} \mathrm{Na}_{2}$ $\mathrm{B}_{4} \mathrm{O}_{7}$ 溶液 $\left(20^{\circ} \mathrm{C}, \mathrm{pH}=7.4\right)$ に移し, Solartron 1172 Frequency Response Analyser を用いて皮膜のインピ ーダンスを測定した。測定周波数範井は $0.1 \sim 10,000 \mathrm{~Hz}$, 対極には白金黒付き白金網を用いた。なお，インピーダ ンスの周波数応答解析の手法の詳細は第 II 報 ${ }^{2)}$ に詳しく 述べてある。

\section{3. 実 験 結 果}

\section{3-1 熱水処理による皮膜のインピーダンス変化}

$0.05 \mathrm{M} \mathrm{CrO}_{4}^{2-}$ 溶液中で種々の時間 $\left(\mathrm{t}_{\mathrm{h}}\right)$ 熱水処理した 皮膜について, インピーダンスの絶対値 $|Z|$ と周波数 $\mathrm{f}$ の関係および位相角 $\theta$ と $\mathrm{f}$ の関係 (ボード線図 ${ }^{2)}$ ) を 求め図 1 に示す。この結果は, 添加剤を含まない熱水中 で処理した場合のものと類似している(第 II 報 ${ }^{2)}$ )。

すなわち, $t_{\mathrm{h}}=0 \mathrm{~min}$ (無処理) の場合には, $\log |Z|$
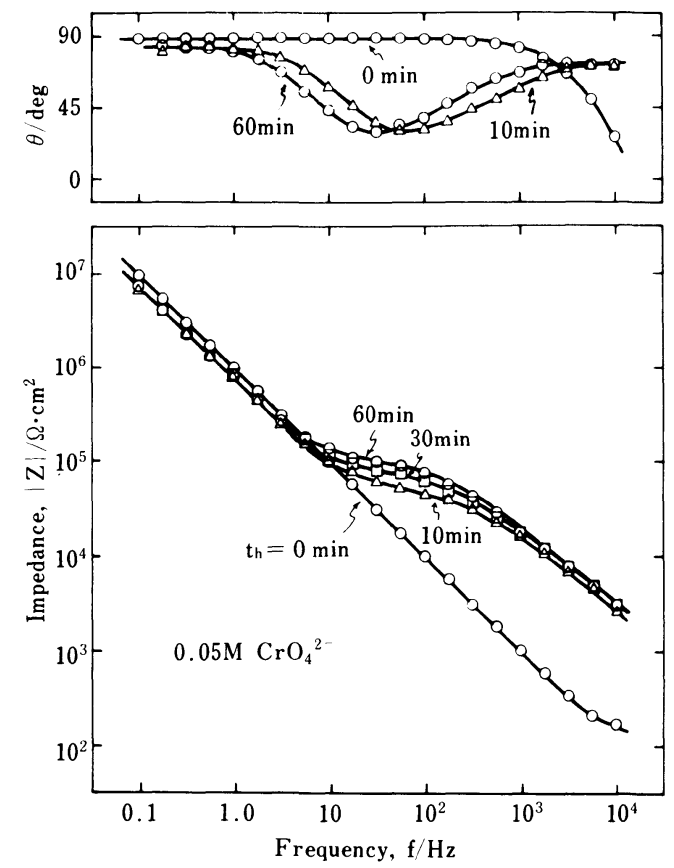

Fig. 1 Time-variations in the $\log |Z|-\log f$ and $\theta-\log f$ curves during the treatment with a hot $0.05 \mathrm{M}$ $\mathrm{CrO}_{4}{ }^{2-}$ solution.

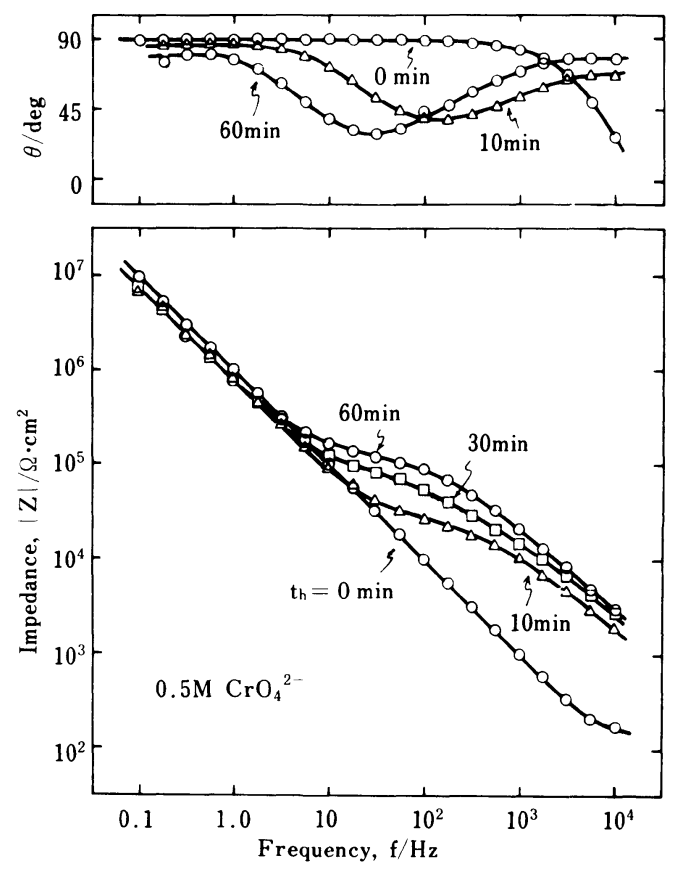

Fig. 2 Time-variations in the $\log |Z|-\log f$ and $\theta-\log f$ curves during the treatment with a hot $0.5 \mathrm{M}$ $\mathrm{CrO}_{4}{ }^{2-}$ solution. 

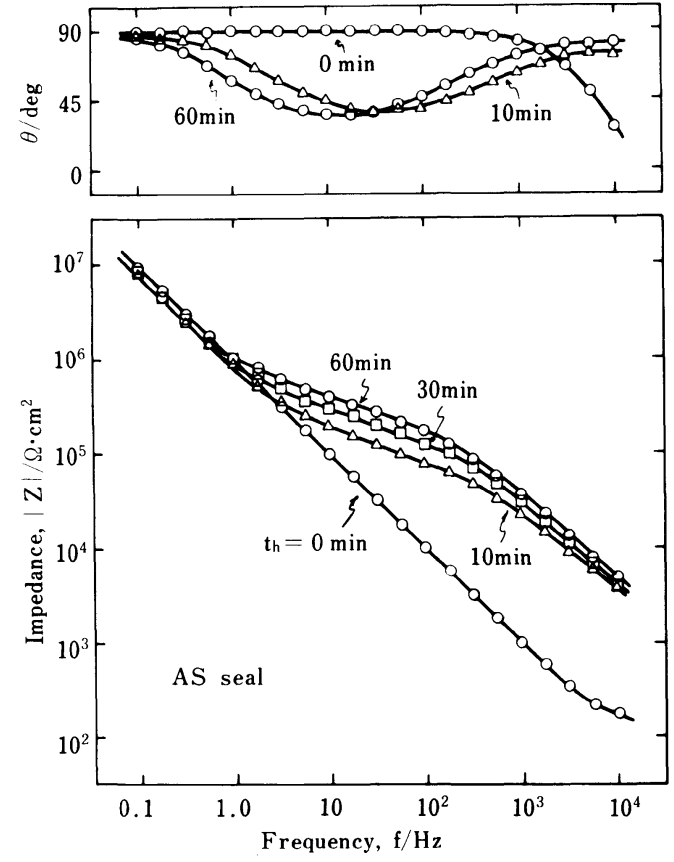

Fig. 3 Time-variations in the $\log |\mathrm{Z}|-\log \mathrm{f}$ and $\theta-\log \mathrm{f}$ curves during the treatment with a hot $5 \mathrm{~g} / \mathrm{l}$ "Sealing" Salt AS solution.
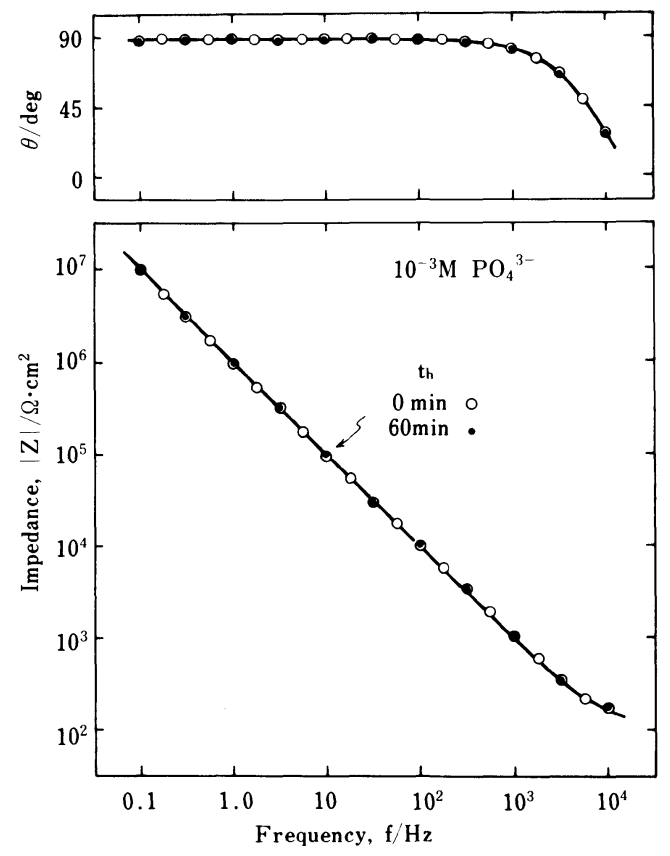

Fig. $4 \log |\mathrm{Z}|-\log \mathrm{f}$ and $\theta-\log \mathrm{f}$ curves obtained before and after the treatment with a hot $10^{-3} \mathrm{MPO}^{8-}$ solution.
〜 log $\mathrm{f}$ 曲線は測定周波数域の大部分で傾き-1の直線で あるが， $t_{\mathrm{h}}$ の増大とともに $\log |Z|$ は，低周波域ではわ ずかに減少し，高周波域では著しく増加する。すなわち， $\mathrm{t}_{\mathrm{h}}>10 \mathrm{~min}$ の場合には, $\log |Z| \sim \log \mathrm{f}$ 曲線の傾きは $\mathrm{f}$ $<10 \mathrm{~Hz}$ ではほぼー $1,10<\mathrm{f}<10^{3} \mathrm{~Hz}$ では0に近づき， $\mathrm{f}>10^{3} \mathrm{~Hz}$ では再びー1に近くなる。この結果は，(1)熱水 処理前の皮膜の等価回路がバリヤー層の容量 $\mathrm{C}_{\mathrm{b}}$ のみで 表わされ，(口)熱水処理後の皮膜のそれは，孔を埋めてい る水和酸化物の容量 $\mathrm{C}_{\mathrm{h}}$ および抵抗 $\mathrm{R}_{\mathrm{h}}$ の並列結合と $\mathrm{C}_{\mathrm{b}}$ との直列結合で表わされることを示す。すなわち, $0.05 \mathrm{M} \mathrm{CrO}_{4}^{2}$-溶液の場合も純水処理の場合と同様に酸 化物の水和反応による封孔が起きている。な抏， $\log |Z|$ 〜 log f 曲線の低周波域および高周波域における傾きー1 の直線の位置より $\mathrm{C}_{\mathrm{b}}$ および $\mathrm{C}_{\mathrm{h}}$ の值が, 中間の周波数 域の $\log |Z|$ の値より $\mathrm{R}_{\mathrm{h}}$ の値を求めることができる。 $\theta$ の値は, $\log |Z| \sim \log \mathrm{f}$ 曲線の傾きがー1のとき $90^{\circ}$ にな

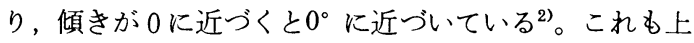
記の等価回路から考えて理解できる。

$0.5 \mathrm{M} \mathrm{CrO}_{4}{ }^{2-}$ 溶液および $\mathrm{AS}$ 溶液で処理した皮膜に ついて得られたボード線図を図 2 扣よび図 3 に示す。こ の結果も0.05 $\mathrm{M} \mathrm{CrO}_{4}{ }^{2-}$ 溶液（図 1）の場合と同様純熱 水で処理したものに類似であり，皮膜の細孔が水和酸化 物で埋められてしまらことに変わりはない。これに対し $10^{-3} \mathrm{M} \mathrm{PO}_{4}{ }^{3-}$ 溶液を用いた場合の挙動は全く異なって

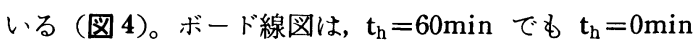
の場合のそれとまったく変わらない。これは $\mathrm{PO}_{4}{ }^{3-} 1$ オンか酸化物表面を覆い, 水和反応の進行を停止させる ためである ${ }^{13)}$ 。

図 5 および図 6 に各種処理溶液に対する $C_{h}^{-1} \sim t_{h}$ 曲 線および $R_{h} \sim t_{h}$ 曲線を示す。ここで $\mathrm{C}_{\mathrm{h}}{ }^{-1}$ は水和酸化 物層の厚さに対応する量である。いずれの溶液について も $\mathrm{C}_{\mathrm{h}}{ }^{-1}$ は $\mathrm{t}_{\mathrm{h}}=10 \sim 20 \mathrm{~min}$ でほぼ定常となり，この時点 で細孔が水和酸化物で完全に埋められると考えられる (ただし, $\mathrm{PO}_{4}{ }^{3-}$ 溶液では $\mathrm{C}_{\mathrm{h}}{ }^{-1}$ と $\mathrm{R}_{\mathrm{h}}$ はともにゼ口である)。 定常となる $\mathrm{C}_{\mathrm{h}}^{-1}$ 值は溶液によって異なるが，これは (イ)

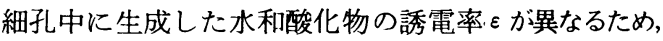
または（口䁩水処理時に皮膜が多少とも溶解し，その程度 によって皮膜の厚さが異なるためであろう。

$\mathrm{R}_{\mathrm{h}}$ は $\mathrm{t}_{\mathrm{h}}>10 \sim 20 \mathrm{~min}$ でも $\mathrm{t}_{\mathrm{h}}$ とともに増大するが， これは $t_{h}$ とともに水和酸化物の比抵抗が増加するため であろ $5^{3)}$ 。0.5 $\mathrm{M} \mathrm{CrO}_{4}{ }^{2-}$ 溶液の場合, $t_{\mathrm{h}}$ の初期に $\mathrm{R}_{\mathrm{h}}$ の増加速度が小さい領域が存在するが，その原因は不明 である14)

\section{3-2 熱水処理による皮膜の重量変化}

純水扣よび各種溶液中で処理したさいの皮膜の重量変 化曲線 ( $\Delta \mathrm{W}_{\mathrm{h}} \sim \mathrm{t}_{\mathrm{h}}$ の関係) を図 7 に示す。0.05 $\mathrm{MCrO}_{4}{ }^{2-}$ 溶液および AS 溶液の場合, 純水の場合と同じように, $\Delta \mathrm{W}_{\mathrm{h}}$ は $\mathrm{t}_{\mathrm{h}}$ とともに増加するが, $\mathrm{t}_{\mathrm{h}}=10 \sim 20 \mathrm{~min}$ 以後あ 


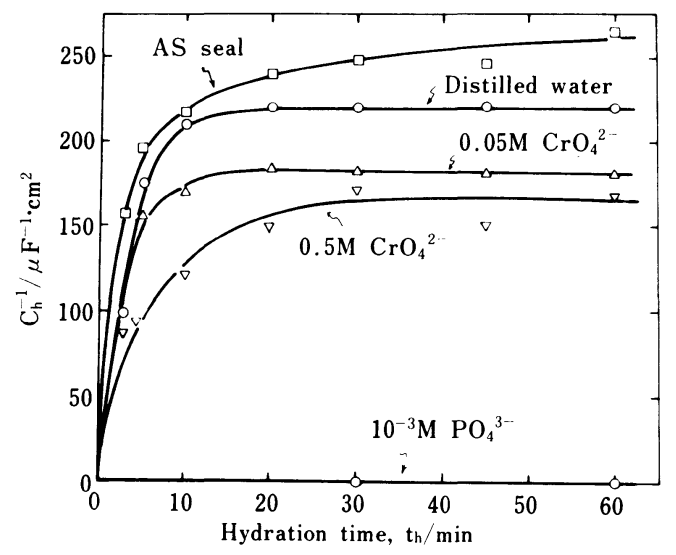

Fig. 5 Changes in $1 / C_{h}$ with time during the treatments in hot water with and without addition of salts and "sealant".

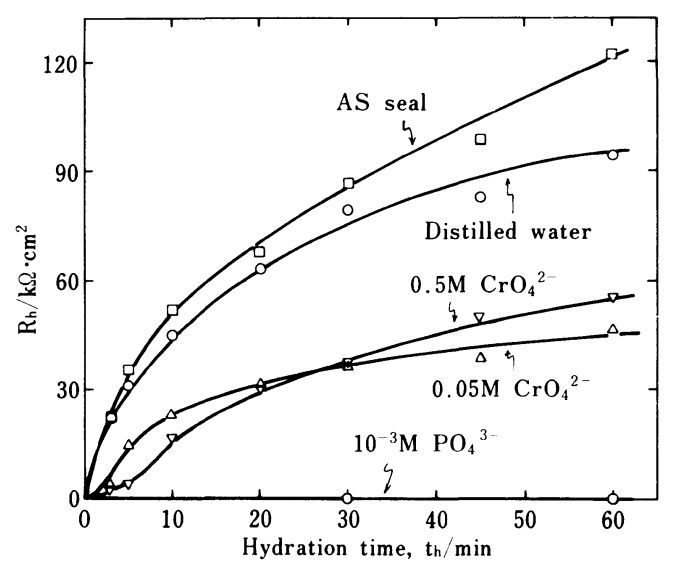

Fig. 6 Changes in $R_{b}$ with time during the treatments in hot water with and without addition of salts and "sealant".

まり変化しなくなる。これはインピーダンス測定の結果 と一致しており，細孔が水和酸化物て埋められてしまう と，それ以後は水和速度が極めて遅くなり重量増加が汪 ぼ停止するのであろう。 $\Delta \mathrm{W}_{\mathrm{h}}$ の值が純水の場合のそれ よりも小さいのは，熱水処理のさい皮膜の溶出が多少起 こるためと考光られる。0.5 $\mathrm{M} \mathrm{CrO}_{4}{ }^{2-}$ 溶夜では $\Delta \mathrm{W}_{\mathrm{h}}$ は $\mathrm{t}_{\mathrm{h}}$ とともに多少减少しているが，これは皮膜の溶解が 著しく, 溶解による減量が水和による重量增をむしろ上 回ってしまらためであろう。皮膜の溶解性は, 純水 $<\mathrm{AS}$ 溶液 $<0.05 \mathrm{MCrO}_{4}{ }^{2-}<0.5 \mathrm{M} \mathrm{CrO}_{4}{ }^{2-}$ の順に大きい といえる。10 $10^{-3} \mathrm{M} \mathrm{PO}_{4}{ }^{3-}$ 溶夜の場合には，水和反応が全 く生起しないばかりでなく, 皮膜は徐々に溶解する。こ れは $\mathrm{Al}^{3+}$ イオンが $\mathrm{PO}_{4}{ }^{3-}$ イオンと可溶性錯体を形成する

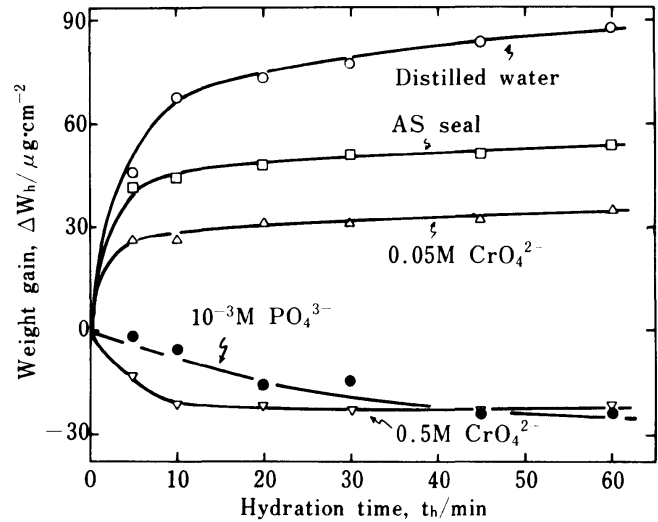

Fig. 7 Changes in the film weight during the treatment in hot water with and without addition of salts and "sealant".

ことによるものであり, $\mathrm{PO}_{4}{ }^{3-}$ 濃度を増せば皮膜の溶解 量がさらに増加することが予想される(5),16)。

\section{3-3 熱水処理皮膜の酸溶解による重量変化}

図 $8 \mathrm{~K} 0.05 \mathrm{M} \mathrm{CrO}_{4}{ }^{2-}$ 溶液中で種々の時間 $\mathrm{t}_{\mathrm{h}}$ 処理し た皮膜をりン酸・クロム酸溶液中で酸溶解したさいの $\Delta \mathrm{W}_{\mathrm{d}} \sim \mathrm{t}_{\mathrm{d}}$ の関係を示す。 $\Delta \mathrm{W}_{\mathrm{d}} / \mathrm{t}_{\mathrm{d}}$ の傾き，すなわち溶解 による皮膜の重量减少速度は $\mathrm{t}_{\mathrm{h}}$ とともに小さくなり， 皮膜の完全溶解に必要な時間は $t_{h}$ とともに長くなる。 熱水処理皮膜の酸溶解速度は細孔を埋めている水和酸化 物の溶解速度に支配されるので1),3)，この結果は，細孔 中の水和酸化物が $t_{h}$ とともに酸に溶けにくくなること を示す。な抗このような溶解速度と $\mathrm{t}_{\mathrm{h}}$ の関係は $0.5 \mathrm{M}$ $\mathrm{CrO}_{4}{ }^{2-}$ 溶液扣よび AS 溶液で処理した皮膜についても 観察された。

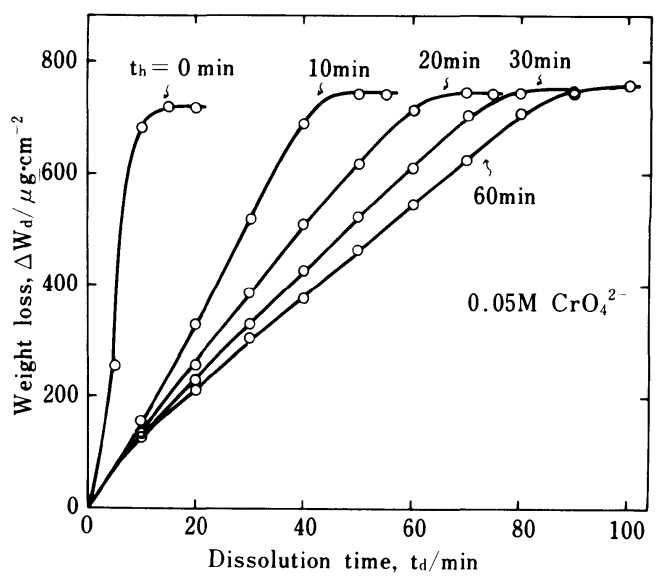

Fig. 8 Changes in the film weight during the acid dissolution experiment. Films were treated with hot $0.05 \mathrm{M} \mathrm{CrO}_{4}{ }^{2-}$ solutions. 
図 9 は各種溶液 $\left(10^{-3} \mathrm{M} \mathrm{PO}_{4}{ }^{3-}\right.$ 溶液は除く) 中で $\mathrm{t}_{\mathrm{h}}=$ $30 \mathrm{~min}$ 処理した皮膜について得られた $\Delta \mathrm{W}_{\mathrm{d}} \sim \mathrm{t}_{\mathrm{d}}$ 曲線で ある。いずれの溶液についても皮膜の溶解速度は無処理 の場合 $\left(t_{h}=0\right)$ のそれより小さくなる。皮膜（すなわち 細孔中の水和酸化物）の溶解速度は，処理液が AS 溶 液 $<$ 純水 $<0.05 \mathrm{M} \mathrm{CrO}_{4}{ }^{2-}<0.5 \mathrm{M} \mathrm{CrO}_{4}{ }^{2-}$ 溶液の順に大 きくなる。このような酸溶解性の相違は, 処理により生 成する水和酸化物の性質（アニオン含量等による）の相 違によるものである。たとえば $\mathrm{CrO}_{4}{ }^{2-}$ 溶液で処理した 場合には, $\mathrm{CrO}_{4}{ }^{2-}$ 濃度が高い汪ど皮膜が多量の $\mathrm{CrO}_{4}{ }^{2-}$ イオンを取り込むので17)，それにつれて溶解速度も大き くなる。一般に, 処理により皮膜中に封入された $\mathrm{CrO}_{4}^{2-}$ イオンは腐食抑制剂として作用するので ${ }^{17)}, \mathrm{CrO}_{4}{ }^{2-}$ 濃度が高い汪ど皮膜の耐食性が向上すると言われている が, この考えは中性の腐食環境はともかく, 酸性環境に ついては適用することができない。

図10は $10^{-3} \mathrm{M} \mathrm{PO}_{4}{ }^{3-}$ 溶液中で種々の時間 $\mathrm{t}_{\mathrm{h}}$ 処理した 皮膜を酸溶解したさいの $\Delta \mathrm{W}_{\mathrm{d}} \sim \mathrm{t}_{\mathrm{d}}$ 曲線を示す。この場 合, $t_{\mathrm{h}}=60 \mathrm{~min}$ 処理しても皮膜の酸溶解挙動は無処理 $\left(t_{h}=0\right)$ のものとほとんど変わらない。これは, 水和反 応がほとんど起こらず細孔は閉ソクしないので当然であ ろら。なお $\mathrm{PO}_{4}{ }^{3-}$ 溶液で処理した皮膜の場合, その耐 食性は基本的には孔底に存在する薄いバリヤー層による と考えられるので, Murphy ら ${ }^{10)}$ の主張する著しい耐食 性の向上は考えにくい。

\section{4. 考察}

多孔質アノード酸化皮膜の熱水処理効率を評価する方 法は封孔度試験と呼ばれるが，これには染色試験，イン ピーダンス (アドミッタンス) 試験および酸溶解試験等

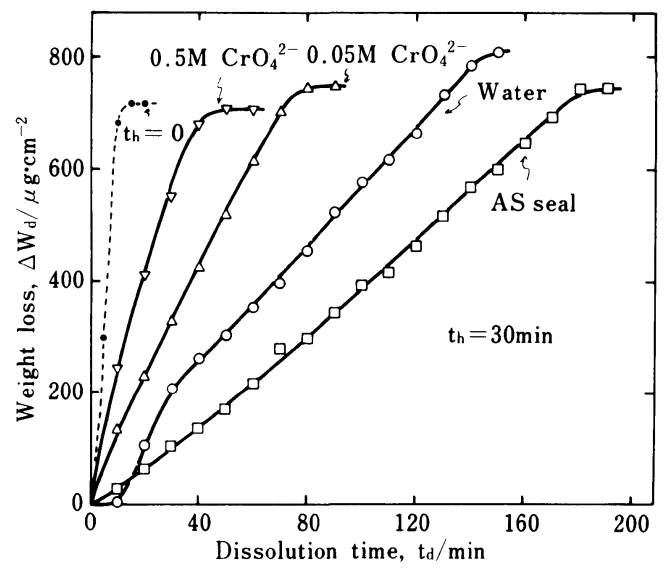

Fig. 9 Changes in the film weight during the acid dissolution experiment. Films were treated for $t_{h}$ $=30 \mathrm{~min}$ in hot water with and without addition of salts and "sealant".
がある ${ }^{18)}$ 。これらの試験の物理的意味は従来不明であっ

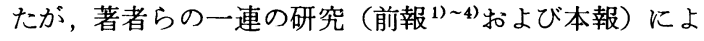
りある程度明らかになった。

染色試験は，もともと皮膜を構成する酸化物の表面の 化学的活性および表面積を定性的に判定するものであり， 熱水処理による皮膜の耐食性の向上の判定には不十分で ある。耐食性は細孔を埋めた水和酸化物の熟成により， 処理時間とともに長時間にわたって増大する性質のもの であり，これに対して染色性は比較的短時間の処理で失 われてしまらので対応関係は乏しいと考えられる5゙。

インピーダンス試験は皮膜の封孔度を $1 \mathrm{k} \mathrm{Hz}$ における 皮膜のインピーダンス值より推定する方法である ${ }^{19) 21) 。 ~}$ 本研究の結果から, $1 \mathrm{kHz}$ 付近の周波数領城では $\mathrm{R}_{\mathrm{h}}$ および $\mathrm{C}_{\mathrm{h}}$ の両方が測定インピーダンス值に寄与する ことが明らかになった。したがって，1k Hz に拉ける皮 膜のインピーダンス值は, 水和酸化物層の厚さおよび比 抵抗が大きいほど，すなわち，もとの皮膜厚が大きいほ ど，また処理時間が長いほど大きくなる。このような条 件では処理皮膜の耐食性が増加するのは明らかであり， $1 \mathrm{k} \mathrm{Hz}$ に打けるインピーダンス值を耐食性の判断基準と して用いることは十分妥当である。しかし，水和酸化物 の生成量, 誘電率, 比抵抗拈よび化学的性質は皮膜の生 成条件や処理条件により異なるので，そのような前歴の 異なる皮膜の耐食性をインピーダンス值のみで比較する ことはできない。なお，測定周波数を $1 \mathrm{kHz}$ すると， $\mathrm{t}_{\mathrm{h}}$ を大きくしてもインピーダンス值があまり変 化しなくなり（ $\mathrm{C}_{\mathrm{h}}$ のみが寄与するため）, $1 \mathrm{kHz}$ 小さくするとインピーダンス值は逆に $\mathrm{t}_{\mathrm{h}}$ とともに減少す る ( $\mathrm{C}_{\mathrm{b}}$ のみが寄与するため)。したがって，測定周波数 を $1 \mathrm{kHz}$ とするのが実用上最も適当である。

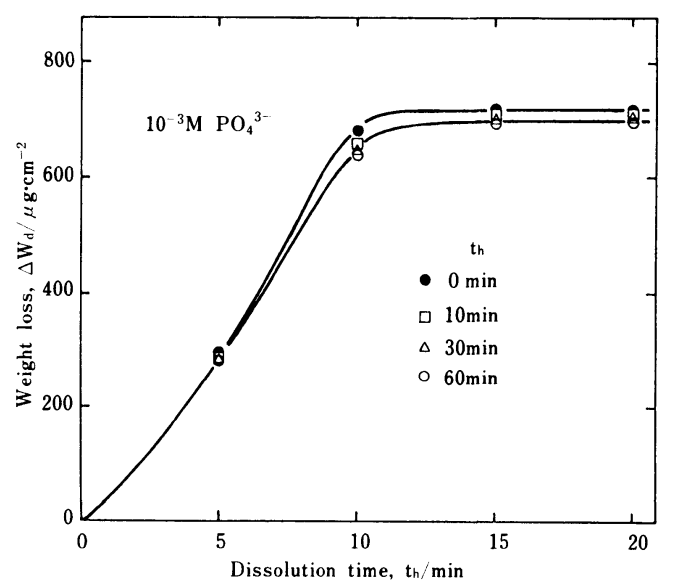

Fig.10 Changes in the film weight during the acid dissolution of the films treated in hot $10^{-3} \mathrm{M} \mathrm{PO}_{4}{ }^{3-}$ solutions. 
皮膜の電気的性質を利用する封孔度試験法には，上述 の方法以外にロス・ファクター（ $\mathrm{d}$ 値）を用いるものが ある ${ }^{22) ~ 24)}$ 。いま皮膜のインピーダンスを $\dot{Z}=\mathrm{a}-\mathrm{bj}($ ま たは $\left.|Z|=\sqrt{a^{2}+b^{2}}\right)$ で表わすとロス・ファクターは $d=$ $\mathrm{a} / \mathrm{b}$ であ。一般にd 值は理論上は膜厚扎よび測定周波 数に無関係であると考えられているが，これは位相角 $\theta$ （= $\tan ^{-1}$ b/a） が広い周波数範囲にわたって一定の場合 （バリヤ一型皮膜や熱水処理していない皮膜の場合）に のみ成立する。熱水処理皮膜の場合, $1 \mathrm{kHz}$ 付近では $\mathrm{R}_{\mathrm{h}}$ と $\mathrm{C}_{\mathrm{h}}$ がともにインピーダンスに寄与するため, $\theta$ す なわち $\mathrm{d}$ 值は測定周波数とともに大きく変化するばか りでなく，皮膜の生成条件および処理条件によっても変 動する。つまり, $\mathrm{d}$ 值を用いて封孔度を判定するのは困

難であろう。

酸溶解試験は，リン酸ークロム酸 ${ }^{25)}$ または酸性亜硫酸 塩 ${ }^{26)}$ 等の酸の水溶液中に処理皮膜を一定時間浸セキした さいの重量减少量を用いて皮膜の封孔度を判定する方法 である。本研究の結果から, 熱水処理により皮膜が酸に 溶解しにくくなるのは次の 2 つの理由によることが明 らかになった。すなわち(イ)細孔が水和酸化物で完全に埋 められ溶解反応の起こる面積が減少するため，および(口) 水和酸化物が熟成作用により酸に溶解しにくいものに変 化する。したがって，一定浸セキ時間における酸溶解量 の多い皮膜については，（）細孔が完全に埋まっていな い，または（ii）細孔が埋まっていても水和酸化物の熟成 が不十分である，の何れによっても説明できるという任 意性はあるが，皮膜の耐食性向上の指標として酸溶解量 を用いることは差しつかえないと思われる。しかし，こ の考えは $\mathrm{CrO}_{4}{ }^{2-}$ 溶液中で処理した皮膜についてはあて はまらない。この場合，皮膜は処理時間とともに次第に 酸に溶解しにくくなるが，純水中で同一時間処理した皮 膜に比べはるかに酸に溶けやすい。しかし，実際の皮 膜の耐食性は $\mathrm{CrO}_{4}{ }^{2-}$ 溶液で処理したものの方がすぐれ ていると言われて扣り，処理方法の異なる皮膜の耐食性 を酸溶解性により比較するのが困難であることがわかる。

以上述べたよらに，現行の封孔度試験はいずれも完璧 なものではなく，またそれらの結果と実用環境における 耐食性との相関関係も十分に調べられていない。したが って, これらの点を明らかにすることが今後の重要な研 究課題であろら。

なお，本研究の遂行に当たり，東洋通商株式会社より Solartron 1172 を拝借し，使用させていただいた。ま た研究費の一部は（財）軽金属奖学会の教育研究資金に
よった。記してあつく感謝する次第である。

（昭和58年 3 月，本協会第67回学術講演大会にて発表）

(1984-5-31 受理)

本論文中の非 S I 単位のS I 単位に対する換算表

\begin{tabular}{|c|c|c|}
\hline 量 & 単位記号 & S I 単位に対する換算率 \\
\hline 電流密度 & $\mathrm{mA} / \mathrm{cm}^{2}$ & $1 \mathrm{~mA} / \mathrm{cm}^{2}=10 \mathrm{~A} / \mathrm{m}^{2}$ \\
\hline 濃度 & M & $1 \mathrm{M}=1 \times 10^{3} \mathrm{~mol} / \mathrm{m}^{3}$ \\
\hline 重 & $\mathrm{Mg} / \mathrm{cm}^{2}$ & $1 \mathrm{Mg} / \mathrm{cm}^{2}=1 \times 10^{-5} \mathrm{~kg} / \mathrm{m}^{2}$ \\
\hline
\end{tabular}

\section{文献}

1）甲田満, 高橋英明, 永山政一; 金表誌， 33，242（1982）

2）甲田満，高橋英明，永山政一; ibid, 33，614（1982）

3）甲田満, 高橋英明, 永山政一; ibid, 34, 44（1983）

4) 甲田満, 高橋英明, 永山政一 ; ibid, 34, 460 (1983)

5) C. Th. Speiser ; Electroplating and Metal Finishing, 9, 109 (1956)

6) G.C. Wood, V.J.J. Marron ; Trans. Inst. Metal Finishing, 45, 17, 107 (1967)

7) S. John, B.A. Shenoi ; Metal Finishing, 74, [7], 31 (1976)

8) M.S. Hunter, P.F. Towner, D.L. Robinson ; Proc, Amer, Electroplaters, Soc., 46, 220 (1959)

9）川瀬寛 ; 軽金属, 21, 120 (1971)

10) C.J. Amore, J.F. Murphy ; Metal Finishing, 63, [12], 50 (1965)

11) J.F. Murphy ; Plating, 54, 1241 (1967)

12）甲田満, 高橋英明, 永山政一; 金表誌, 28，584（1977）

13) H. Konno, S. Kobayashi, H. Takahashi, M. Nagayama ; Corr, Sci., 22, 913 (1982)

14) T.P. Hore, G.C. Wood ; Electrochim, Acta, 7, 333 (1962)

15）向井峰夫，高橋英明，永山政一; 金表第67回講演大会予稿 集 p.90

16) H. Takahashi, M. Mukai, M. Nagayama ; Proceeding of the 9th Intnl. Congr. on Metallic Corrosion (1984), Toronto, Vol.2, p. 155

17) N.D. Tomashov, A. Tyukina ; Light Metals, 9, 22 (1946)

18）長坂秀雄編 ; 金属表面工業用 I.S.O. 規格，槙書店 (1981)

19) E.T. Englehart, D.J. George ; Materials Protection, 3 , [11], 24 (1964)

20) W. Leute, H. Birtel ; Aluminium, 41, 53 (1965)

21) H. Birtel, W. Leute ; ibid, 43, 93 (1967)

22）松下静夫;アルミニウム研究会誌，115，12（1977）

23) E. Survila, D.P. Andrew ; Trans. Inst. Metal Finishing, 54, 163 (1976)

24）金成真平；実技誌，31，108（1984）

25) J.H. Manhart, W.C. Cochran ; Plating, 58, 219 (1971)

26) P.G. Sheasby, R.D. Guminski, T.K. Castle ; Trams. Inst. Metal Finishing, 44, 50 (1966) 